\title{
Intercultural peer tutoring competences as a part of learning development in an international higher education context
}

\author{
Jannike Hille \\ European University Viadrina, Germany \\ Gundula Gwenn Hiller \\ European University Viadrina, Germany \\ Stefanie Vogler-Lipp \\ European University Viadrina, Germany
}

\begin{abstract}
In the framework of the internationalisation of Higher Education (HE), this case study exposes the innovative concept of training intercultural peer tutors, and its implications. We will argue which skills are considered as specific intercultural peer tutoring competences and why these are important for the learning development in internationalised learning contexts. After a short description of the intercultural peer tutoring training at the European University Viadrina (EUV) and its theoretical basis, we will present the findings of a study accompanying the beginning phase of the training, which will demonstrate what kind of competences intercultural peer tutors develop in addition to those associated to classical peer tutoring. The paper will show that this specific training, focusing on intercultural peer tutoring, has a considerable impact on students' own intercultural learning progress and also substantially prepares them to support the learning development of fellow international students.
\end{abstract}

Keywords: international students; intercultural peer tutoring; intercultural competences; learning support. 


\section{Introduction}

Peer tutoring is not a new concept but has particularly gained traction in Germany since 2011 with the 200 million euro funded 'Teaching Quality Pact' programme of the Federal Government: this programme aims to improve study conditions and the quality of teaching and mentoring for students in HE. Within this framework, a peer tutoring training has been initiated by EUV, exceptional in its dimensions and differentiation. In this paper we will present one training specialisation of the peer-tutoring programme at the EUV relating to intercultural peer tutoring, which, as far as we know, is unique and innovative in Germany. We will explain why we focused on intercultural peer tutoring competences, what competences students developed, how we defined these competences and how we trained peer tutors.

With the internationalisation of HE comes a strong increase in student and teacher mobility, but this also brings new diversity, which has its own set of challenges for teaching and learning. Recent research has shown that there are significant differences in academic practices in general (Ryan, 2013) and that studying in Germany is especially complex for international students because of the very specific German academic system, particularly in the humanities (e.g. Hiller, 2013; Schumann, 2012; Ricken, 2011).

With $25 \%$ of its student body comprised of international students, the EUV is one of the most multicultural universities in Germany. It has therefore been very concerned with the questions related to diversity in learning (Hiller, 2007). The EUV is situated at the GermanPolish border and students find themselves in an international surrounding, with many challenges including: different learning practices, teaching styles and academic communication (both oral and written), language barriers, unknown roles and hierarchy patterns, the different grading system, etc. (Hiller, 2014; Knapp and Schumann, 2008). Study programmes with significant international orientation and student composition have resulted in a highly intercultural internal structure of the university. This has resulted in all parties having to develop specific competences to deal with this diversity. The training of students in intercultural competences has been recommended by both practitioners and researchers (Hiller, 2007; Knapp and Schumann, 2008; Bosse, 2010). 
Otten et al. (2013, p.243) argue that the international teaching context requires a new dimension of intercultural understanding which includes the reflection of one's own and others' teaching and learning practices.

The Viadrina Centre for Intercultural Learning has therefore been developing various programmes with the aim of enhancing intercultural awareness within the institution. The 'Viadrina PeerTutoring' training enabled EUV to establish a specific intercultural training specialisation for peer tutors, which augments students' intercultural competence and trains them to support their fellow students in intercultural learning development.

In the following, we will point to the potential and importance of development and training of intercultural competence within 'Viadrina PeerTutoring' and, in this context, will argue which competences are included and why they are extremely supportive for learning development in an international institution.

We consider the multi-layered 'Viadrina PeerTutoring' programme to be a classical activity of learning development, as it involves students by teaching them how to deal with the multiple challenges found in teaching and learning and by training them how to tutor their peers in the beginning phase of their studies. The training programme aims to improve study conditions within the context of internationalisation and the quality of teaching and mentoring for students in HE. Students learn to reflect on their practices and how to professionally accompany and support fellow students' learning processes and how to manage peer-facilitated learning arrangements.

We will particularly focus on the intercultural peer tutoring specialisation, its training programme, its learning targets and its developed intercultural peer tutoring competences which have not yet been, in our opinion, clearly demonstrated before. Thus, the study explains what specific intercultural peer tutoring competences are meant to be accomplished and how students evaluate their skill acquisition.

\section{Background}

In 2012, the 'Viadrina PeerTutoring' training programme was established to operate across disciplines and spread into different areas of key competences, such as intercultural 
competence, writing, learning and presentational skills. It is integrated in the curriculum of all faculties at the EUV (including Business Administration and Economics, Faculty of Law as well as Social and Cultural Science), therefore all Bachelor and Masters students may voluntarily attend the training. Students receive credit points as well as an official certificate that documents the personal as well as the professional development gained in the programme. The training programme consists of four modules which may be attended independently from each other.

\section{Figure 1. 'Viadrina PeerTutoring' training at the European University Viadrina}

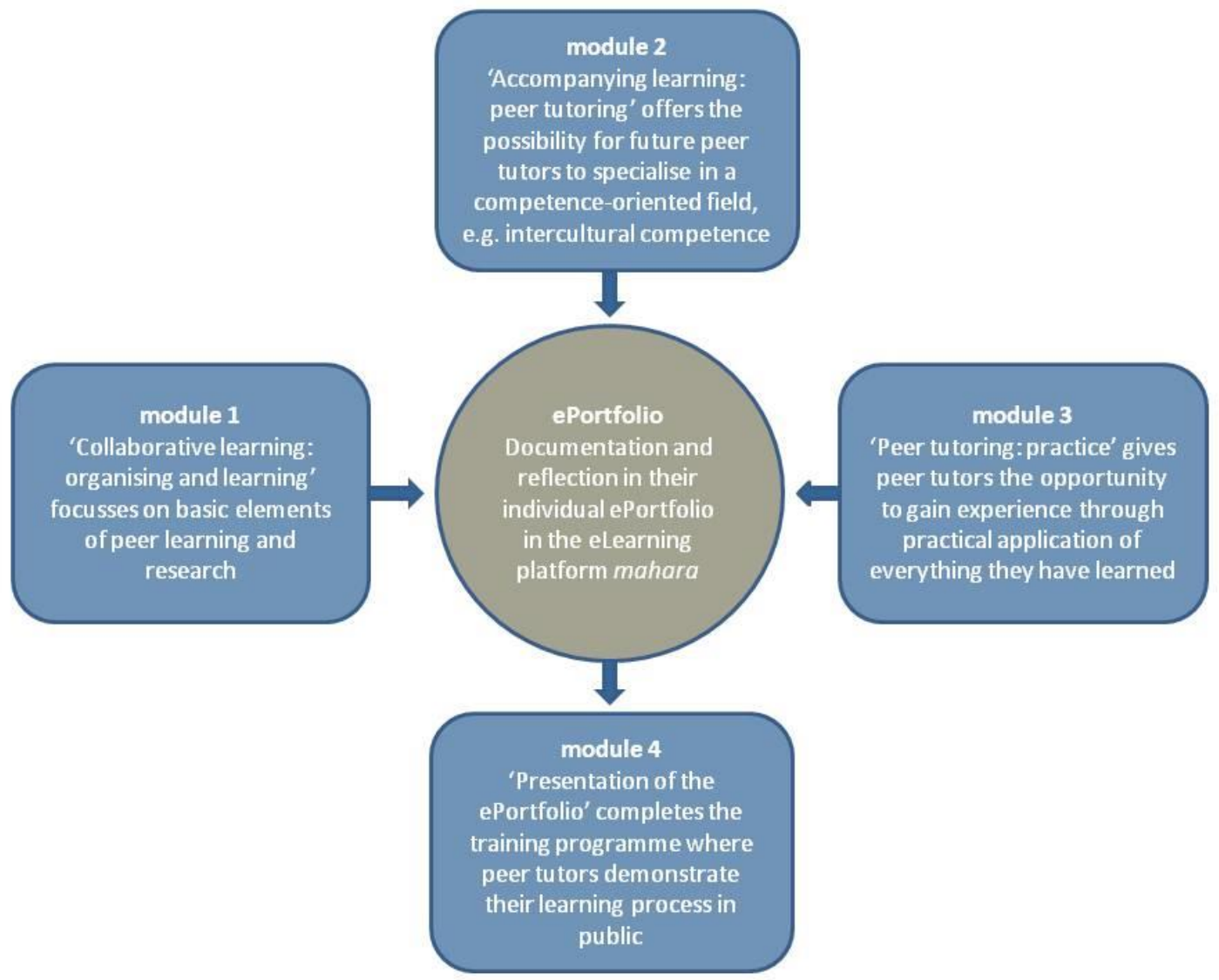

Students participating on the 'Viadrina PeerTutoring' training will need at least one semester either summer (April-July) or winter (October-February) to complete the training. It is also possible to complete it in two separate semesters, e.g. summer and winter. The training programme is based on peer learning theory. Boud defines the basic concept of peer learning as:

Students learning from and with each other in both formal and informal ways. (Boud, 2001, p.4). 
Peers learn, interact and create new knowledge with and from each other. They also work on an eye-to-eye-level with hardly any hierarchy (Boud, 2001; Falchikov, 2001; Bruffee, 1984). As far as we know, there is no established model of intercultural peer tutoring. That being said, we were convinced from the very beginning that peer tutoring and intercultural learning would operate very well and could be established at the EUV, as it is such an international university. We believed the existence of intercultural peer tutors to be important as they actively create and contribute to a welcoming culture within this university.

It is our opinion that the high percentage of international students coupled with the EUV's close location to Poland, as well as the overall internationalisation process of universities, makes the training of intercultural peer tutors highly relevant and necessary. Furthermore, we believe that particularly within an international university, the exchange between students and peer tutors may be productive for both sides. On the one hand, international students are accompanied by peer tutors who are experts in intercultural learning and intercultural methods with the aim of supporting them and their studies and, on the other hand, intercultural peer tutors learn from their peer tutoring activities to take responsibility for their own actions, reflect and organise their own learning process, and learn from other cultures.

Within 'Viadrina PeerTutoring', intercultural peer tutors are trained in intercultural awareness, knowledge of different teaching and learning cultures, and how to sensitise international students to develop their intercultural competence to be prepared for studying in the German academic system. Furthermore, intercultural peer tutors learn how to interpret and react in difficult and challenging interactions, how to cope with the cultural specificities of the German university system and how to analyse and use intercultural training methods and tools. They learn how to design and conduct workshops, for example one-day workshops or two-day excursions with eight to twenty participants. They also offer counselling hours and summer school programmes or support faculty seminars through the delivery of short practical intercultural units. During their employment peer tutors attend methodological and intercultural supervision training. There are also team meetings with other peer tutors, to consult and discuss specific challenges or to talk through and reflect upon critical incidents that they may have experienced. 
We train intercultural peer tutors to develop and strengthen their intercultural competence, seen as:

...the ability to interact effectively and appropriately in intercultural situations; it is supported by specific attitudes and affective features, (inter)cultural knowledge, skills and reflection. (Boecker and Ulama, 2008, p.4).

We are convinced that these areas may be used within the 'Viadrina PeerTutoring' with the appropriate tools and methods. We are confident that these skills can be developed through the 'Viadrina PeerTutoring' programme, with the appropriate tools and methods.

Within the training programme the most important tool is reflection, based on an ePortfolio. According to DeSeCo (2005) reflection during academic studies is the core of the key competences and needs to be considered very carefully. During their training, students reflect on their theoretical knowledge as well as their practices. Through Fink's (2013) learning taxonomy we determined the learning outcome of the ePortfolios as follows:

- Students know how and why they reflect.

- They know how they may apply reflection as a learning device in and outside the classroom.

- They are aware of what media competence they have developed.

- They know how to design their individual ePortfolio.

- They know how to give peer feedback.

One best practice example, showcasing that ePortfolios are appropriate to use in a HE learning context especially in the area of intercultural competence, is a field report by Kilian-Yasin (2013). In this report, ePortfolios were used to improve the integration of foreign as well as international students and the internationalisation in everyday study life. Kilian-Yasin's field report encouraged us to use ePortfolios within the intercultural peer tutoring training, which may be used to help intercultural peer tutors to learn and reflect on their learning process. The above mentioned and listed learning outcomes may strengthen the frame for learning development and make learning in an international context more transparent and effective. 
In order to improve and show the relevance of the concept of intercultural peer tutoring at the Viadrina and strengthen its existence the following study was conducted.

\section{Evaluation of the training programme}

One of the authors of this article examined the intercultural peer tutoring specialisation within her Master's thesis: this survey identified which aspects of intercultural competence the peer tutors achieved during their training. The study and its results will be outlined in the following.

\section{Participants}

In total, eight ePortfolios written by EUV students who took part in the 'Viadrina PeerTutoring' training programme were examined. The participating students were from all faculties of the EUV. They consisted of first-year students and undergraduates. Each participant signed a consent form to allow the academic team to use his or her ePortfolio for research and evaluation purposes. The programme creators guaranteed that the ePortfolio was anonymised. The participants were asked to sign the consent form voluntarily.

\section{Data}

The training programme participants conducted ePortfolios, which reveal their learning development of intercultural peer competence in a highly reflective way. These ePortfolios served as a basis for the evaluation. The study therefore analyses and examines the students' self-evaluation. (For purposes of simplification the term 'ePortfolio 'covers both electronic portfolios and non-electronic portfolios. The numbering system refers to the original numbering assigned within the Master's thesis.)

The data includes a total of eight ePortfolios (including four paper portfolios: P1-P4; and four electronic portfolios: EP1-EP4), presented to some extent on the eLearning platform 'mahara' by participants in the 'Viadrina PeerTutoring' training programme. 


\section{Method}

The theoretical frame and research method is built on a combined method, i.e. the data was analysed with qualitative content analysis (Schreier, 2012) by using an encoding technique. The codes refer to the categories of the intercultural competence model defined by the 'Intercultural Competence Assessment (INCA) Project' (Prechtl and Davidson-Lund, 2007) as well as on categories referring to specific learning targets defined by the programme creators. The qualitative content analysis requires a coding grid, in order to find codes corresponding to the pre-defined categories. This grid was developed on the basis of:

- Five intercultural competences, according to the INCA project.

- Four specific intercultural peer tutoring competences which, according to Viadrina PeerTutoring (based on the learning targets of the intercultural peer tutoring specialisation), have been shown to be relevant (see Table 1).

Table 1 below shows the categories that served as a grid for the encoding process.

Table 1. Definitions of intercultural (peer tutoring) competences.

\section{Intercultural competences (based on Prechtl and Davidson-Lund, 2007)}

\begin{tabular}{|l|l|}
\hline Knowledge discovery & $\begin{array}{l}\text { Intellectual curiosity about other cultures and motivation to gather } \\
\text { information to discover culture related-knowledge, in order to } \\
\text { interact better with people. }\end{array}$ \\
\hline Behavioural flexibility & $\begin{array}{l}\text { Adapting behaviour to a specific situation and presenting a broad } \\
\text { knowledge of one's repertoire. }\end{array}$ \\
\hline Communicative awareness & $\begin{array}{l}\text { Willingness to modify existing conventions and having appropriate } \\
\text { negotiation conventions for intercultural communication. }\end{array}$ \\
\hline Respect for others & $\begin{array}{l}\text { Equal treatment of different behaviour, value and convention } \\
\text { systems, due to the willingness to respect diversity and coherence. }\end{array}$ \\
\hline Empathy & $\begin{array}{l}\text { Willingness to take the other's perspective and awareness of } \\
\text { diverse perspectives. }\end{array}$ \\
\hline
\end{tabular}

Intercultural peer tutoring competences (based on peer learning targets)

\begin{tabular}{|l|l|}
\hline $\begin{array}{l}\text { Methodological expert } \\
\text { knowledge }\end{array}$ & $\begin{array}{l}\text { Competence to understand and analyse features of intercultural } \\
\text { encounters and to apply learned expertise, e.g. essential theories } \\
\text { and concepts. }\end{array}$ \\
\hline Cooperation & Willingness for collaborative learning and working with peers. \\
\hline Peer learning support & Ability to support and accompany peers in intercultural learning \\
\hline
\end{tabular}




\begin{tabular}{|l|l|}
\hline & $\begin{array}{l}\text { settings. The application of methodological knowledge to empower } \\
\text { peers in order to improve their intercultural competence. }\end{array}$ \\
\hline Intercultural peer & $\begin{array}{l}\text { Awareness that helps to handle and be responsive in situations of } \\
\text { intercultural interaction and understanding how to support peers to } \\
\text { develop intercultural competence. }\end{array}$ \\
\hline
\end{tabular}

The overall aim of the survey was to analyse ePortfolios with regard to the gain of intercultural competence perceived by peer tutors during their training. All of the above codes (definitions) were analysed in-depth in the participants' ePortfolios. Incisive points concerning intercultural development were observed, highlighted, categorised and allocated in accordance with the specific intercultural categories outlined in Table 1. In addition, the intercultural competence categories were quantified (i.e. it was noted which categories were mentioned very often, if they could be put together in a possible correlation, or if they were only rarely or once mentioned). The definitions of intercultural competence categories were based on those identified within the INCA model and those identified by EUV: these collectively formed the basis for this altered empirical method of evaluation. Thus a detailed picture of students' individually experienced acquirement of intercultural peer tutoring competences within the 'Viadrina PeerTutoring' programme and their learning development could be drawn.

\section{Results}

The evaluation of the ePortfolios (regarding intercultural competence in the field of peer tutoring in $\mathrm{HE}$ ) indicates that, on the one hand, all competences considered by the programme developers were mentioned but, on the other hand, a huge variety in viewpoints concerning the students' learning process were revealed. Due to limited space, we have summarised representative statements in the following table. They are sorted according to the pre-defined codes (definitions) previously outlined in Table 1 as 'intercultural (peer tutoring) competences'. The following exemplary statements expose the student's reflection of their own development within the learning process of intercultural competence. (All citations are taken from the original data and were translated by the authors from German into English.) 


\section{Table 2. Statements presenting intercultural competences in the ePortfolios by participants in the 'Viadrina PeerTutoring' training programme.}

\begin{tabular}{|c|c|}
\hline \multicolumn{2}{|c|}{ Intercultural competences } \\
\hline $\begin{array}{l}\text { Knowledge } \\
\text { discovery }\end{array}$ & $\begin{array}{l}\text { I generally see my intercultural learning process as a spiral because the } \\
\text { theoretical and practical examination with a topic stimulates again and again new } \\
\text { influences and new thinking processes, and through changes and dynamics of } \\
\text { cultures never develops a permanent picture. [...] the conscious and written } \\
\text { examination with a newly learned topic motivates continued thought and the } \\
\text { learning process is by no means stagnated. (P4: p.3) }\end{array}$ \\
\hline $\begin{array}{l}\text { Behavioural } \\
\text { flexibility }\end{array}$ & $\begin{array}{l}\text { For my learning process I definitely also take along flexibility which is connected } \\
\text { to teamwork. (P2: p.2) }\end{array}$ \\
\hline $\begin{array}{l}\text { Communicative } \\
\text { awareness }\end{array}$ & $\begin{array}{l}\text { Inquiry practices in particular as well as active listening and paraphrasing are } \\
\text { aspects I would like to further practice and develop. I am convinced that a } \\
\text { successful consultation depends on conversation techniques [...] In the future I } \\
\text { would like to give more attention to ask my counterpart where the problem or } \\
\text { issue lies. In case of misunderstandings there cannot occur a good consultation. } \\
\text { (P4: p.7) }\end{array}$ \\
\hline $\begin{array}{l}\text { Respect for } \\
\text { otherness }\end{array}$ & $\begin{array}{l}\text { Peer learning }[\ldots] \text { indeed facilitates the personality development, because you } \\
\text { learn to respond to other team colleagues and to debate with them [...]. (P1: p.2) }\end{array}$ \\
\hline Empathy & $\begin{array}{l}\text { During the analysis the participants are invited to put themselves into all involved } \\
\text { person's (or parties) positions. Through looking at a conflict from different } \\
\text { perspectives, they can learn to develop appreciation and empathy for diverse } \\
\text { ways of thinking and acting. Furthermore, a change of perspectives can lead to } \\
\text { visualising the reason behind a conflict -which can be attributed for instance to } \\
\text { the different cultural norms and values of the participants [...]. (EP4.1) }\end{array}$ \\
\hline \multicolumn{2}{|c|}{ Intercultural peer tutoring competences } \\
\hline $\begin{array}{l}\text { Methodological } \\
\text { expert } \\
\text { knowledge }\end{array}$ & $\begin{array}{l}\text { [...] triggered me to be engaged with the theory of peer tutoring within the } \\
\text { intercultural context. The interaction with my colleagues motivated me to test a } \\
\text { new dimension for peer tutoring work, bringing me new knowledge and leaving } \\
\text { enough space for creativity and fantasy. (P2: p.5) }\end{array}$ \\
\hline Cooperation & $\begin{array}{l}\text { More and more it showed that we interact very thoughtfully, although we did not } \\
\text { necessarily consort with each other outside the lecture/ small group or have the } \\
\text { same interests. I'm tracing it back to the fact that we all engaged with the peer } \\
\text { learning situation, that we experienced the tension and dissymmetry with respect } \\
\text { and benefit from it. We encourage, broaden and mutually support each other. (P3: } \\
\text { p.16) }\end{array}$ \\
\hline $\begin{array}{l}\text { Peer learning } \\
\text { support }\end{array}$ & $\begin{array}{l}\text { Through our collective experiences and shared thirst for knowledge, we grew } \\
\text { together as a group during the time of the lecture. Therefore it has been } \\
\text { established that a huge mutual trust would not have been possible without such a }\end{array}$ \\
\hline
\end{tabular}


successful learning. (P1: p.16)

\begin{tabular}{|ll|}
\hline Intercultural & The participants shall be alerted to their own 'cultural spectacles' and perception \\
peer awareness & structures. This sensitisation generates awareness of 'other' interpretation \\
& possibilities and explanatory approaches of actions, which are seemingly \\
& suggested, due to one's own cultural imprint. At best the participants \\
& experience/learn a certain competence and how to interact in future intercultural \\
& situations. (P3: p.9)
\end{tabular}

These examples are representative of the students' reflections and self-evaluation. Each statement (Table 2) presents the diverse ways in which the participating students experienced and reflected upon their intercultural learning development led by the 'Viadrina PeerTutoring'. The findings give the programme developers important insights into the demands, notions, conclusions and conditions of intercultural learning in HE. Being aware that these results reflect only students' self-evaluation, which is subjective, we can nevertheless conclude the strengths and potential for improvement of our programme.

One important result of the study was that empathy and respect for others are frequently mentioned competences in the ePortfolios and have a visible correlation. Through this we see that these two competences have been especially crucial for the students' learning experience. Other competences such as communicative awareness, which we also consider to be highly important in this context, should have more emphasis put on them in the future.

The study identified which intercultural peer tutoring competences can be developed within our training programme, with empathy and respect for others being highlighted by the peer tutors themselves. Yet, the findings of our study give only a glimpse into the students' learning process. Students' ePortfolios are written reflections of their own learning development and lack assessment by others. All reflection processes point to selfevaluation and self-centred motivation. Further studies should be broader and include, for example, empirical examinations of students' peer guidance work. 


\section{Conclusion}

The study showed that 'Viadrina PeerTutoring' is a precious contribution to learning development in international contexts: the university's institutional setting, the proximity to the Polish border, the amount of international students and the increasing process of internationalisation in universities overall, justifies and demands the action of intercultural peer tutors supporting their international fellow students in learning development.

'Viadrina PeerTutoring' is unique in Germany with its interplay between quality, length, and supervision of the intercultural peer tutors. The intercultural peer tutors have a wide range of duties: they conduct intercultural workshops, counselling hours and summer school programmes and contribute to faculty seminars through the delivery of short practical intercultural units targeting new international students, to prepare and support them for their study in Germany. To do this, they require specific training which raises their own intercultural competence. Moreover, they must be trained to design and conduct workshops, which help fellow international students accommodate themselves to the German academic culture. We therefore established an important contribution to learning development in interculturalism and diversity, by developing and implementing a training programme, the success of which has been demonstrated in the here-presented study. There has been a benefit and advancement of intercultural competence within the duration of the 'Viadrina PeerTutoring' training programme as observed in the ePortfolios. The participants valued a positive and impressive development success during the training programme. Thus, this first evaluation confirms what our experience has shown so far, that the existence of intercultural peer tutors is important, because they may actively create and contribute to a welcoming culture within the German university, and that the training programme is a win-win-situation, since both tutors as well as the supported students learn and increase their intercultural and learning competences. Finally, we consider that intercultural competences are an important aspect of peer tutoring in the international context, and the specific competences of peer learning support have an exceptional role to play in the frame of learning development. 


\section{References}

Bosse, E. (2010) 'Vielfalt erkunden - ein Konzept für interkulturelles Training an Hochschulen', in Hiller, G.G. and Vogler-Lipp, S. (eds.) Schlüsselqualifikation interkulturelle Kompetenz an Hochschulen: Grundlagen, Konzepte, Methoden. Wiesbaden: VS Verlag für Sozialwissenschaften, pp. 109-133.

Boud, D. (2001) 'Introduction: making the move to peer learning', in Boud, D., Cohen, R. and Sampson, J. (eds.) Peer learning in higher education: learning from and with each other. London: KoganPage, pp. 1-20.

Bruffee, K. A. (1984) 'Collaborative learning and the conversation of mankind', College English, 46(7), pp. 635-652.

Boecker, M.C. and Ulama, L. (2008) Intercultural competence - the key competence in the $21^{\text {st }}$ century?, Theses by the Bertelsmann Stiftung and the Fondazione Cariplo (based on the models of intercultural competence by Dr. D. K. Deardorff). Available at:

http://www.ngobg.info/bg/documents/49/726bertelsmanninterculturalcompetences.p df (Accessed: 5 July 2015).

Definition and Selection of Competencies: Theoretical and Conceptual Foundations (DeSeCo) (2005) Definition und Auswahl von Schlüsselkompetenzen: Zusammenfassung, pp.1-12. Available at:

http://www.deseco.admin.ch/bfs/deseco/en/index/03/04.parsys.97111.downloadList. 89603.DownloadFile.tmp/2005.dskcexecutivesummary.ge.pdf (Accessed: 18 December 2015).

Falchikov, N. (2001) Learning together: peer tutoring in higher education. London: RoutledgeFalmer.

Fink, L.D. (2013) Creating significant learning experiences: an integrated approach to designing college courses $2^{\text {nd }}$ edn. San Francisco: Jossey-Bass. 
Hiller, G.G. (2007) Interkulturelle Kommunikation zwischen Deutschen und Polen an der Europa-Universität Viadrina. Eine empirische Analyse von Critical Incidents. Frankfurt: IKO-Verlag

Hiller, G.G. (2013) 'Internationalität und Grenzlage als Lernressource', in von Helmolt, K., Berkenbusch, G. and Jia, W. (eds.) Interkulturelle Lernsettings: Konzepte - Formate - Verfahren. Stuttgart: ibidem-Verlag, pp. 109-136.

Hiller, G.G. (2014) 'Kulturelle und sprachliche Diversität in der Hochschule - am Beispiel von E-Mail-Kommunikation', in Moosmüller, A. and Möller-Kiero, J. (eds.) Interkulturalität und kulturelle Diversität: Münchner Beiträge zur interkulturellen Kommunikation. Münster: Waxmann, pp. 233-258.

Kilian-Yasin, K. (2013) Portfolio - international Studieren: Internationalisierung des Curriculums durch interkulturelle Kompetenz und Integration. Available at: https://publikationen.unituebingen.de/xmlui/bitstream/handle/10900/43956/pdf/TBHD KilianYasin IV 13032 1 Korr7 Enddruck.pdf?sequence=1\&isAllowed=y (Accessed: 23 September 2015).

Knapp, A. and Schumann, A. (eds.) (2008) Mehrsprachigkeit und Multikulturalität im Studium. Frankfurt: Peter Lang.

Otten, M., Hertlein, S. and Teekens, H. (2013) 'Hochschullehre als interkulturelles Lernsetting', in von Helmolt, K., Berkenbusch, G. and Jia, W. (eds.) Interkulturelle Lernsettings: Konzepte - Formate - Verfahren. Stuttgart: ibidem-Verlag, pp. 243266.

Prechtl, E. and Davidson-Lund, A. D. (2007) 'Intercultural competence and assessment: perspectives from the INCA project', in Kotthoff, H. and Spencer-Oatey, H. (eds.) Handbook of Intercultural Communication. Berlin: Mouton de Gruyter, pp. 467-490.

Ricken, J. (2011) Universitäre Lernkultur: Fallstudien aus Deutschland und Schweden. Wiesbaden: VS Verlag für Sozialwissenschaften. 
Ryan, J. (2013) 'Introduction', in Ryan J. (ed.) Cross-cultural teaching and learning for home and international students: internationalisation of pedagogy and curriculum in higher education. London: Routledge, pp.1-12.

Schreier, M. (2012) Qualitative content analysis in practice. London: Sage Publications.

Schumann, A. (ed.) (2012) Interkulturelle Kommunikation in der Hochschule: zur Integration internationaler Studierender und Förderung interkultureller Kompetenz. Bielefeld: transcript Verlag.

\section{Author details}

Jannike Hille is a family assistant and care supervisor for people with learning difficulties and works in the field of accompanied parenthood. In 2014 Jannike graduated from the European University Viadrina, Frankfurt (Oder) in Intercultural Communication Studies. Her master's thesis, entitled 'About the purchase of intercultural competence at the university: can intercultural competence be obtained from peer tutoring? Based on the peer tutoring training at the European University Viadrina, Frankfurt (Oder)', investigates the 'Viadrina PeerTutoring' programme initiated by the Centre for Intercultural Learning. In her empirical study she was interested in analysing the student's learning development and self-assessed acquirement of intercultural competences within this peer programme.

Gundula Gwenn Hiller, PhD, is the director of the Centre for Intercultural Learning at the European University Viadrina in Frankfurt (Oder), where she has designed different programmes concerned with the students' development of intercultural competence. Her research and teaching area is intercultural communication and competence acquisition in the context of internationalisation of Higher Education and cultural divergences in teaching and learning practices. Due to her knowledge of different languages and her interest in other cultures, she has a wide experience in teaching in international contexts and abroad (e.g. USA, Poland, Turkey, Italy, France).

Stefanie Vogler-Lipp is a scientific researcher at the Centre for Intercultural Learning at the European University Viadrina in Frankfurt (Oder). She is currently working in the 'Viadrina 
PeerTutoring' programme. She is teaching and supervising the intercultural peer tutors. She is working on her dissertation on the improvement and development of the reflection competence concerning the individual learning process within the intercultural peer tutoring training. Her teaching and research focus is on intercultural competence in Higher Education, peer learning and diversity. 